\title{
El imaginario medieval de la política salvadoreña
}

Estudio iconológico e iconográfico de la campaña proselitista de ARENA y el FMLN en la campaña electoral de 2009

José Manuel GonzÁlez Departamento de Letras, Comunicaciones y Periodismo UCA, San Salvador jgonzalez@comper.uca.edu.sv

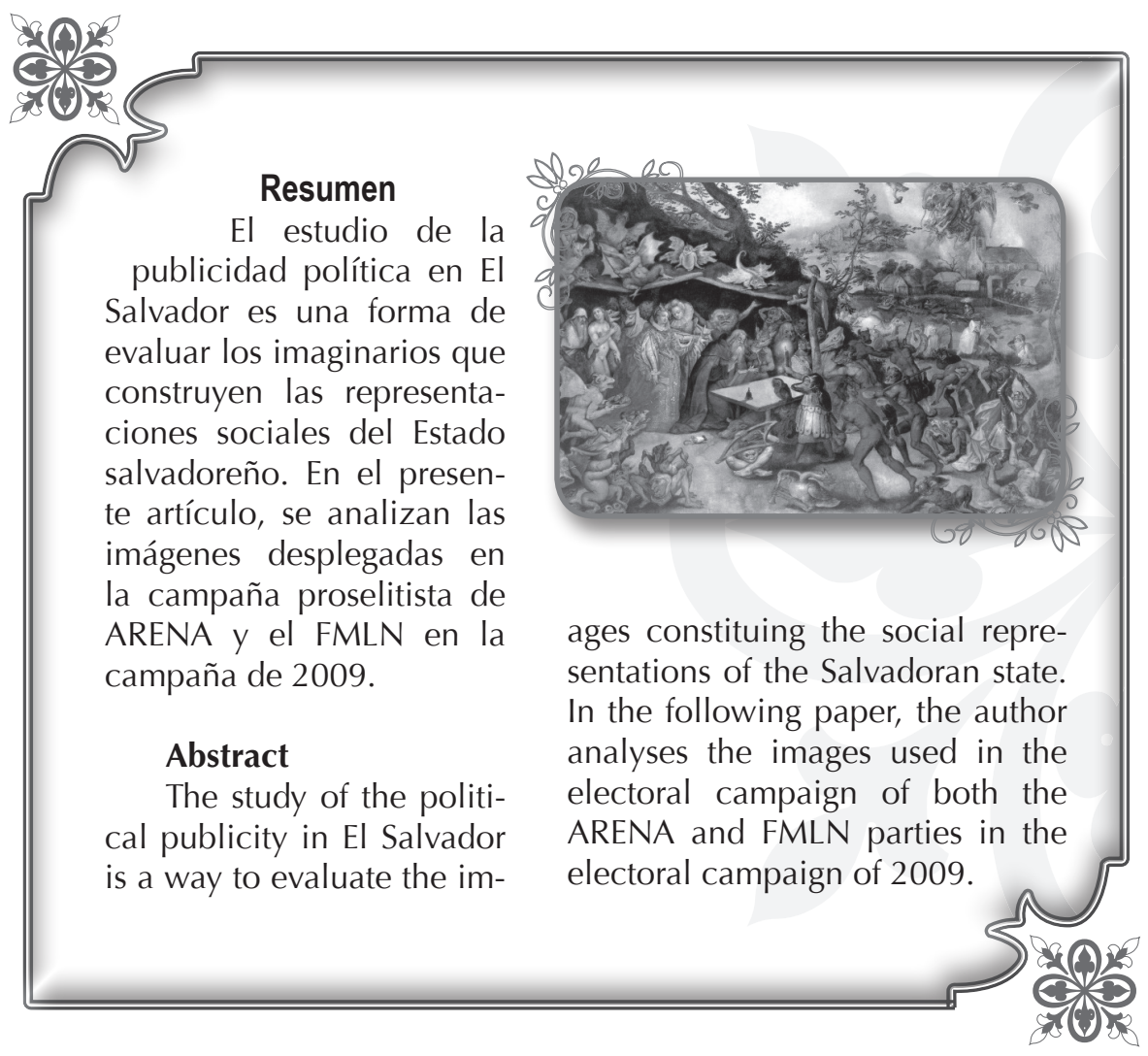


$\mathrm{R}$ oland Barthes, al hablar de la fotografía publicitaria en su libro El sistema de la moda, afirma: "En el interior de la comunicación fotográfica conforma un lenguaje específico que tiene, sin duda alguna, su léxico y su sintaxis, sus 'giros' prohibidos o aconsejados". En efecto, la publicidad construye un texto organizado en el que el mundo representado, fotografiado y ensamblado adquiere, por un lado, los niveles escénicos del teatro y por otro se completa con las dimensiones semánticas del documento visual, tan válido para recrear entornos como para construir criterios de validez.

Si bien la política en El Salvador presenta figuras con matices de tabloides amarillistas, con notas de farándula y escándalo, no es el objeto de este artículo hablar sobre la imagen de moda de los candidatos a la presidencia, sino abordar los códigos convencionales que se han mantenido presentes en los entramados discursivos de la publicidad política, esos imaginarios heredados culturalmente y a menudo enmascarados por un mensaje propagandístico articulado con la intención de exaltar a uno frente a la discriminación del otro.

La escenificación en sí misma traduce las imágenes emblemáticas de principio a fin, se alimenta de íconos establecidos en la dinámica de la sociedad salvadoreña y adquiere fuerza representativa cuando recrea hechos y espacios tan coti- dianos y comunes a la memoria popular. La tarea inicial es, entonces, estudiar esas imágenes con valor emblemático, reconocerlas como idiolectos propios de una tradición de representaciones (en este caso de la mitología cristiana occidental) y evaluar cómo en su dinámica interior se consolidan valores semióticos importantes.

Obviamente, para una visión conservadora, el cruce de los códigos que se propone parecerá no sólo especulativo, sino hipotético o hasta subjetivo; sin embargo, al desarticular el entramado del mensaje y observar las partes estructuradas en el mismo, desde la elección del escenario, la presencia de figuras particularmente elegidas (para representar diversos sectores de la población salvadoreña) y el aparecimiento oportuno de las figuras políticas ya reconocidas se podrán evidenciar los códigos ampliamente compartidos e intencionalmente representados con la finalidad de perpetuar el mismo pensamiento mítico ordenador del sistema de vida actual donde la condena, la culpa, el caos y el final son las armas más precisas para generar resignación, autocensura y continuismo con los sistemas dominantes vigentes.

Para la realización de este estudio se ha tomado la campaña publicitaria de los dos partidos en contienda política, Alianza Republicana Nacionalista (ARENA) y el Frente Farabundo Martí para la Liberación Nacional (FMLN), trans- 
mitida en la televisión nacional, principalmente desde noviembre de 2008 hasta marzo de 2009, con el fin de evaluar tres aspectos concretos presentes en la línea discursiva de la publicidad política:

La publicidad de la derecha propició una campaña radicalmente segregante y excluyente, en la que se apela a lo ético, a la responsabilidad y a la conciencia salvadoreña como mecanismos de control y corrección social. Por su parte, la publicidad de la izquierda mantuvo la evaluación y el señalamiento de las deficiencias de los veinte años de gobierno de ARENA. Esta fue una respuesta directa a la estrategia de desprestigio presente en la campaña de ARENA y otros grupos emergentes en dicha coyuntura política. Con ella se apeló a la evaluación consciente y a la comparación del sistema de vida y el desarrollo alcanzado por cada salvadoreño individualmente durante la administración arenera.

La contienda política adquirió los niveles de una guerra de imá- genes y colores institucionales, en la que el oponente fue visto como enemigo y los simpatizantes como rivales en el campo de batalla. La polarización del estado durante el proceso electoral fue antidemocrática, sin participación de la voz ciudadana y no abonó al diálogo. Contrario a ello, tanto la derecha como la izquierda, cada una a su proporción, se concentraron en emitir mensajes cuya función estaba centrada en cuestionar a su oponente, con evidente desmesura por parte de ARENA.

Como un elemento curioso en el discurso proselitista de estas elecciones del 2009, ambas instituciones políticas recurrieron a imágenes comunes, emblemáticas y alegóricas, homogenizando su campaña y presentando un discurso no ortodoxo en función de las líneas de cada partido en contienda. La iconografía militante del socialismo realista será la protagónica tanto en los mensajes de ARENA como del FMLN, aunque con matices discursivos propios de cada línea política.

\section{La cruzada por El Salvador}

a patria, como alegoría, es el espacio sagrado de vida y desarrollo, la consolidación imaginaria del estado nacional que en sus heráldicas nacionalistas se vuelve particular, y por tanto, construye al salvadoreño y lo diferencia de los demás en el mundo. La patria, como símbolo, es el motivo por el cual hay que luchar, es la dama a defender y resguardar, es el tesoro a mantener y potenciar. Independientemente de 
donde se observe, la patria se convierte en un emblema propio de la contienda en las campañas políticas.

La construcción publicitaria de la patria adquiere escenificaciones ideales, con predicciones positivas o negativas, capaces de motivar la participación ciudadana en una apuesta simbólica, en la cual se reestructuran el pensamiento mítico, las creencias populares, las anécdotas colectivas y las costumbres religiosas; todas ellas capaces de darle forma a una reserva de imágenes que alimentarán códigos visuales con significaciones y sentidos COyunturales. Gauthier (1986) dirá, en este sentido, que la intención es producir sentido reproduciendo un fragmento del espacio percibido que no planteará ningún problema de reconocimiento al espectador.

El horizonte de contienda fue lo que más apareció en la publicidad política del 2009, con enfoques completamente distintos en su abordaje discursivo; sin embargo, tanto el FMLN como ARENA apelaron a la defensa, la lucha y el llamado a la gesta como recurso de identidad con el salvadoreño. Dios fue el paralelo de la patria, y más que una campaña política, el proselitismo se transformó en una guerra santa en pro de la democracia. La cruzada fue la expresión más básica del proceso electoral y evidenció el desequilibrio político en función de fuerzas y entidades del panorama nacional. En efecto, el ambiente salvadoreño en total fue el campo de batalla simbólico donde la derecha dominante manifestó una narrativa grandilocuente y opresiva, tanto visual como discursivamente $y$, a su vez, la izquierda se movió con alternativas estratégicas y narrativas de evaluación y cuestionamiento.

Las alianzas emblemáticas del discurso de ARENA fueron la tradición caudillista de la cultura salvadoreña y la alusión a la cruzada religiosa más bélica en pro de imponerse frente a enemigos que amenazaban los valores nacionales heredados y defendidos con la lucha. El rescate del patriotismo sagrado se visualizó como recurso de una predicción apocalíptica en potencia, y la amenaza fantasma tomó forma en figuras externas a El Salvador como Hugo Chávez y el socialismo del siglo XXI. Todo buen salvadoreño debía enarbolar su voto y defender con pecho henchido de orgullo nacionalista a su patria.

El llamado a la batalla se visualiza como una necesidad consciente del 'buen ciudadano', se demanda en forma imperativa a los emblemas siguientes: el padre responsable de su familia, al ciudadano soberano responsable de su democracia, al creyente virtuoso responsable de su práctica de fe y al hombre honesto responsable de su desarrollo, todos ellos ahora, caballeros cruzados, héroes anónimos y nacionalistas convocados por la heráldica de ARENA a hondear el partido por la defensa de la libertad, sacro tesoro, santificado por la muerte heroica de los padres de la patria. 
Cuadro 1:

Valoración iconográfica de la publicidad política en la campaña presidencial 2009

\begin{tabular}{|l|l|l|l|l|}
\hline & \multicolumn{1}{|c|}{ El Estado } & \multicolumn{1}{c|}{ Héroe } & \multicolumn{1}{c|}{ Oponente } & \multicolumn{1}{c|}{ Ciudadano } \\
\hline ARENA & $\begin{array}{l}\text { Espacio sagrado } \\
\text { a defender } \\
\text { Reino Justo y } \\
\text { en desarrollo } \\
\text { cristiano } \\
\text { Dama en peligro }\end{array}$ & $\begin{array}{l}\text { El ciudadano } \\
\text { convocado } \\
\text { El guerrero } \\
\text { anónimo } \\
\text { El fiel, } \\
\text { creyente, } \\
\text { patriarca }\end{array}$ & $\begin{array}{l}\text { El demonio } \\
\text { dictatorial a } \\
\text { someter } \\
\text { La amenaza } \\
\text { periférica } \\
\text { El retroceso }\end{array}$ & $\begin{array}{l}\text { Coaccionado } \\
\text { e interpelado: } \\
\text { Moralmente } \\
\text { Religiosamente } \\
\text { Nacionalmente }\end{array}$ \\
\hline FMLN & $\begin{array}{l}\text { Espacio } \\
\text { profanado a } \\
\text { rescatar } \\
\text { Reino sometido } \\
\text { Nación a } \\
\text { rescatar }\end{array}$ & $\begin{array}{l}\text { El legislador } \\
\text { conciente } \\
\text { El monarca } \\
\text { ilustrado } \\
\text { El patriarca } \\
\text { juez }\end{array}$ & $\begin{array}{l}\text { El delito } \\
\text { impune } \\
\text { El corrupto y } \\
\text { corruptor a } \\
\text { castigar } \\
\text { El continuismo }\end{array}$ & $\begin{array}{l}\text { Condicionado y } \\
\text { Comprometido: } \\
\text { Conocimiento } \\
\text { Evaluación } \\
\text { Cambio }\end{array}$ \\
\hline
\end{tabular}

La lucha por la libertad en la campaña del FMLN se visualiza en otra línea discursiva, aunque con elementos igualmente coincidentes de gesta: la bandera de El Salvador, la pluma, la constitución y la Biblia se convirtieron en armas de una lucha santa, moral, conciente y recta. La variación discursiva de estos préstamos iconográficos religiosos se observó en la alusión a un voto consciente, inclusivo y evaluador, una narrativa proactiva aunque guiada por el héroe ilustrado. En efecto, Mauricio Funes adquirió la personificación del guerrero monarca, justo, que en lugar del cetro y el orbe sostenía la constitución y la pluma, amparados por la fe y defendiendo la nación, por ende, dispuesto a la batalla.

Ambos partidos generaron una campaña de enemigos y militan- cias, abonaron a la polarización política y a la segregación social. Los patrones culturales aprendidos en los cantares de gesta medievales cobraron forma en imágenes grandilocuentes, con una narrativa moldeada por cuatro actantes fundamentales: el estado, el héroe, el oponente y el ciudadano. Sin embargo, la publicidad de ARENA estructuró la dinámica de la dama en peligro que demanda el surgimiento del héroe de condición moral probada, un discurso final tan amenazante, agigantando al enemigo y segregando radicalmente a los simpatizantes de una u otra línea política. El ciudadano se vio coaccionado a elegir entre ser bueno o malo, santo o profano, defensor o agresor sin opciones intermedias. 
La misma articulación de actantes se observa en el mundo generado por el FMLN en su campaña, con diferencias semánticas substanciales. Por una parte, se alude a la imagen del caballero justo y juez, con una posición ilustrada, conocedora $y$, por ende, probada en función de sus competencias personales como líder político; el Estado se define en la campaña del FMLN como sometido a injusticias, negligencias, corrupciones y el oponente adquiere la dimensión de una administración indolente, más que a un personaje específico, es el continuismo en el gobierno y su mala administración a lo que hay que vencer. El ciudadano se convoca a una participación proactiva y por condición, evaluando el estado de desarrollo alcanzado individualmente en estos veinte años de gobierno de ARENA.

Así la cruzada por El Salvador tenía como empeño construir un sólido bloque de militantes o guardianes heroicos que con su voto defenderían los valores patrios, conquistando o imponiéndose ante el enemigo $\mathrm{o}$, por el otro frente discursivo, rescatando el país y reivindicando los verdaderos valores nacionales. Sin embargo, la debilidad de estas construcciones emblemáticas de la mitología medieval radicó en la fragmentación del poder, porque tanto ARENA como el FMLN aluden a la iconografía del héroe individual, caudillista en la derecha y dirigente en la izquierda, pero ambos con posturas patriarcales atribuidas. Es claro que la homogenización del imaginario contribuyó a favorecer una dinámica narrativa de emblemas rutinarios, coincidentes y vigentes en la representación del estado salvadoreño, hecho que se observará en mayor grado en la mitología publicitaria.

\section{Los emblemas y heráldicas de la mitología política en la publicidad}

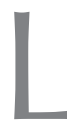

a publicidad política en El Salvador exterioriza las presunciones didácticas de un mensaje ilustrado, en su estructura narrativa, asume como lector a un público cautivo que solo consume frases hechas y que no interactúa con el emisor; la publicidad se vuelve entonces unidireccional y dibuja al ciudadano salvadoreño como un objeto publicitario no como un su- jeto con el cual dialogar. Los espots publicitarios presentan los hechos desde un narrador omnisciente, conocedor y vigilante, con la responsabilidad de asesorar al ciudadano y tutelar su elección de voto. En este sentido, las propuestas de gobierno, la discusión de ideas, la apertura política y la disposición al diálogo con sus interlocutores es desplazado por productos visuales recicla- 
dos, eslóganes rítmicos y clichés de campañas que solo reclaman notoriedad pública y presencia visual en el ecosistema visual de El Salvador.

La campaña proselitista está fundamentada en una serie emblemática de lo que Gauthier nombra "símbolos de rutina", emblemas e imágenes replicados, trivializados o sacralizados que aluden a un pensamiento visual tradicional o fundamentalista propio de la tradición mítica religiosa. El mensaje de la campaña no es producido sino simplemente actualizado, moderniza escenarios, actores, acciones repetitivas y en muchas ocasiones insubstanciales. Los códigos y convenciones de la tradición partidaria más básica saturan la atmósfera y hacen visible la democracia política a través de primeros planos y planos detalle, donde lo importante es una mano sin rostro marcando una bandera emblemática en la papeleta. La democracia es solo un procedimiento y la elección del ciudadano es tangible en personajes tan homogéneos y anónimos que abren el espectro simbólico a lo genérico.

Ambos partidos políticos en contienda generaron una campaña publicitaria de emblemas y heráldicas mitológicas, aludiendo a la imagen de la tierra prometida, la Biblia, los valores éticos y morales y los símbolos patrios como forma de señalar los pilares fundamentales sobre los que se basa la propuesta política de las instituciones que representan.

La democracia se volvió tangible y se experimentó en una serie de elementos plásticos tan estilizados como investidos de sentido particular: acciones, gestos y personajes programados con anticipación poblaron las pantallas televisivas y las vallas publicitarias, junto a la imagen del candidato a la presidencia o las banderas y colores institucionales. Un ama de casa, un obrero, un campesino, un joven universitario, se mueven en escenarios cuidadosamente seleccionados e investidos de significación emblemática para alegorizar la libertad democrática y la condición soberana del pueblo salvadoreño.

En esta representación publicitaria de la democracia, ambos partidos políticos facilitaron la polarización del Estado y, en esa guerra de imágenes, símbolos y heráldicas, el proceso electoral anuló la verdadera discusión de ideas por una sobre exposición de actantes oponentes, enemigos y contrarios con rasgos visuales tan impersonales como generalizados en los que los colores, las banderas y otros emblemas los definen. En efecto, independientemente del slogan, la deficiente locución, el incipiente escenario y la actuación teatralizada, los modelos elegidos deben de representar códigos genéricos con un estricto anonimato personal. De la misma forma, las campañas anteriores han recurrido a la misma propaganda emblemática y heráldica de rutina, en los que presentan un país de preocupaciones laborales, económicas, de inseguridad y de salud en voz de campesinos, amas de casa, jóvenes, obreros, 
íconos que plastifican la voz y participación del pueblo salvadoreño en el ámbito político, estandarizando el código visual en la escenificación de la democracia.

Las variantes discursivas son en cambio, elementos de mayor estu- dio, pues aún cuando tanto ARENA como el FMLN acuden a los mismos símbolos de rutina para mantener el lazo de identidad y comunicación efectiva con el votante salvadoreño, el mensaje final se estructura de acuerdo a la tradición política de cada partido.

\section{Cuadro 2:}

Valoración narrativa de la democracia y libertad, codificación semántica de la publicidad de ARENA y el FMLN

\begin{tabular}{|l|l|l|}
\hline $\begin{array}{l}\text { Partido } \\
\text { político }\end{array}$ & Campaña emitida & \multicolumn{1}{c|}{ Pautas narrativas } \\
\hline ARENA & $\begin{array}{l}\text { Piensa, reflexiona } \\
\text { Vota con sabiduría } \\
\text { Vota por tu libertad } \\
\text { Vota por ARENA }\end{array}$ & $\begin{array}{l}\text { - Alude a la comparación entre lo bueno y } \\
\text { lo malo. } \\
\text { - El ciudadano es libre de elegir, pero debe } \\
\text { elegir bien o sufrir las consecuencias. } \\
\text { - El partido se vuelve alternativa favorable, } \\
\text { se limita una sola opción. }\end{array}$ \\
\hline FMLN & $\begin{array}{l}\text { Votarías por cinco } \\
\text { años más } \\
\text { Vota FMLN } \\
\text { Un cambio seguro } \\
\text { Esta vez es diferente } \\
\text { Con Mauricio } \\
\text { presidente }\end{array}$ & $\begin{array}{l}\text { - Alude a la enumeración de las acciones } \\
\text { corruptas toleradas por el gobierno de ARENA. } \\
\text { - El ciudadano se ve confrontado en una } \\
\text { dialéctica personal, evalúa la eficacia } \\
\text { administrativa del continuismo en el gobierno } \\
\text { frente a la viabilidad tangible del cambio. } \\
\text { - El partido se vuelve alternativa favorable, la } \\
\text { opción de un gobierno diferente. }\end{array}$ \\
\hline
\end{tabular}

La campaña de ARENA se concentra en deslegitimar al FMLN como fuerza política, o como partido homólogo con sus propias dimensiones sociales, culturales y políticas paralelas, construye un discurso segregante en relación bueno-malo, lo legítimo e ilegítimo, lo civilizado-incivilizado, etc. en el cual el FMLN es presentado como una fuerza subversiva y no como un instituto político; es el enemigo a vencer a reprimir y no con el cual dialogar.

Los íconos de rutina propios de este discurso dominante y represivo serán expresiones plásticas de esta orientación discursiva: las manifestaciones ciudadanas concebidas como remanentes de la acción subversiva y por ende desautorizadas como expresiones populares en pro 
de una causa social o política. La presencia de gremios, asociaciones y organizaciones ciudadanas junto a sus expresiones grupales son entendidas como actos vandálicos con actitudes guerrilleras presentes en la quema de llantas, grafittis, daños a la propiedad pública y bloqueo de caIles. Frente a esta construcción publicitaria del enemigo, el ciudadano se define como el responsable directo de elegir entre un partido que refleja la seguridad social o uno que representa la inestabilidad y el conflicto.

El FMLN, por su parte, produjo una campaña de respuesta a la campaña desinformativa de la derecha, pero con el énfasis en la evaluación y señalamiento de la mala administración del estado en los cuatro gobiernos de ARENA; una apuesta discursiva proactiva y no reactiva que rompió con la recurrente queja de las campañas anteriores. De igual forma, presentó variaciones emblemáticas sustantivas, dejó de lado el peso de los colores institucionales y la imagen militante del partido de izquierda para convertirse en una publicidad evaluadora que apela a la conciencia colectiva y a la opción responsable y decidida. En repetidas ocasiones se escuchó a Mauricio Funes diciendo: 'Si ellos hubieran gobernado bien y si tuvieran propuestas para el futuro no tendrían que hacer campaña sucia'; es por ello que el cuestionamiento del oponente en los spot del FMLN convocó a un ciudadano fiscalizador, crítico, participativo y libre de miedos y represiones; fue la pro- puesta de una dialéctica discursiva en la que ARENA se presentó como una fuerza política que recurre a la mentira, al miedo, a la coerción para mantener su sistema represivo y segregante.

El retroceso, la falta de desarroIlo y oportunidades son los principales indicadores de la mala administración del Estado, expresados en las representaciones emblemáticas del pueblo con jóvenes, adultos mayores, oficinistas así como también en tierras sin siembras, escasez de alimentos y medicinas, así como la distribución desmedida de la riqueza a favor de unos cuantos. Frente a lo anterior, las multitudes corriendo en las calles, hondeando banderas de El Salvador y del FMLN, Ios rostros sonrientes, los transportes colectivos completamente Ilenos serán las alegóricas muestras del cambio esperanzador investido de las heráldicas unidas en la presencia de ambas banderas.

La continua recurrencia a imágenes emblemáticas de 'lo salvadoreño' genera un nivel básico de comunicación con el electorado. Independientemente del partido, la evocación al progreso y los niveles de desarrollo serán formas para evaluar a unos o condenar a otros; en este sentido, la confrontación política produjo una exposición de imágenes, personificaciones y símbolos que se escudaron en heráldicas de guerra polarizada y segregante. Es notable, sin embargo, la actitud proactiva de la publicidad del FMLN 
evidenciando, como se ha expuesto, sus variantes discursivas.

\section{(e)}

3. Iconografías compartidas

paso sin transición hacia el mito. De esta forma, los esquemas podrán presentar múltiples variantes formales pero las relaciones icónicas fundamentales que ayudan a la eficacia del mensaje, no se verán alteradas.

Sin embargo, aún cuando estas imágenes se mantengan constantes en la publicidad salvadoreña, no deben estudiarse desde un solo punto de vista, su significación final estará articulada por la relación sintagmática del mensaje, así como por el juego estereotipado del mundo referenciado en él. La fuerza emblemática no sólo está en la reproducción del espacio cotidiano salvadoreño, sino también en la adecuación de un esquema imaginario propio de occidente que en la publicidad política del 2009 aludió particularmente a un imaginario cristiano occidental.

\section{Cuadro 3:}

Constantes iconográfícas en la publicidad politica de ARENA y el FMLN

\begin{tabular}{|l|l|l|}
\hline Iconografía & ARENA & FMLN \\
\hline \multirow{4}{*}{ La nación } & Unidad nacional & Un nuevo país \\
& Valores: Dios, patria, familia, & Valores: Paz, esperanza, \\
& trabajo y libertad & unión \\
& Voto por ARENA es voto por & Voto de confianza para un \\
& El Salvador & país diferente (esta vez) \\
\hline
\end{tabular}




\begin{tabular}{|c|c|c|}
\hline Iconografía & ARENA & FMLN \\
\hline El pueblo & $\begin{array}{l}\text { Doméstico, hermanos, familia } \\
\text { unida } \\
\text { Beneficiados por Red Solidaria, } \\
\text { Semilla Mejorad y Fosalud } \\
\text { Vida nueva }\end{array}$ & $\begin{array}{l}\text { Desengañado } \\
\text { Decidido } \\
\text { Principal beneficiado } \\
\text { Gente triunfante }\end{array}$ \\
\hline El campesino & $\begin{array}{l}\text { Beneficiado con Semilla } \\
\text { Mejorada } \\
\text { Caminos rurales } \\
\text { Trabajo y reconstrucción }\end{array}$ & $\begin{array}{l}\text { Abandono del agro } \\
\text { Escasez crediticia } \\
\text { Carestía de alimentos }\end{array}$ \\
\hline El joven & $\begin{array}{l}\text { Salvador que genera } \\
\text { oportunidades } \\
\text { Diferente a los anteriores } \\
\text { Feria de empleos }\end{array}$ & $\begin{array}{l}\text { Falta de oportunidades } \\
\text { Falta de empleos } \\
\text { Capacidad frustrada }\end{array}$ \\
\hline La madre & $\begin{array}{l}\text { Beneficiada por las remesas } \\
\text { Preocupada por sus hijos } \\
\text { Preocupada por la estabilidad y } \\
\text { seguridad social }\end{array}$ & $\begin{array}{l}\text { Sostén del hogar } \\
\text { Mujer sometida por la falta } \\
\text { de oportunidades } \\
\text { Luchadora y decidida } \\
\end{array}$ \\
\hline El obrero & $\begin{array}{l}\text { Beneficiado por la empresa } \\
\text { privada } \\
\text { Preocupado por la estabilidad } \\
\text { laboral } \\
\text { Padre, esposo, ciudadano } \\
\text { patriota }\end{array}$ & $\begin{array}{l}\text { Busca la superación por el } \\
\text { estudio } \\
\text { Oportunidad de empleos } \\
\text { dignos } \\
\text { Mejores condiciones de vida }\end{array}$ \\
\hline El oponente & $\begin{array}{l}\text { Chávez y el FMLN } \\
\text { Una milicia popular, una fuerza } \\
\text { guerrillera, criminales } \\
\text { Sometimiento y dictadura } \\
\text { Satélite del imperio }\end{array}$ & $\begin{array}{l}\text { El adversario abusador } \\
\text { Miedo y falsas promesas } \\
\text { Desigualdad y corrupción } \\
\text { Estancamiento y retraso } \\
\text { Promesas no cumplidas }\end{array}$ \\
\hline El tiempo & $\begin{array}{l}\text { Acción presente (piensa, } \\
\text { reflexiona) } \\
\text { Continuismo como estabilidad } \\
\text { Duración y estabilidad de las } \\
\text { acciones }\end{array}$ & $\begin{array}{l}\text { El futuro contra el pasado } \\
\text { El cambio contra el } \\
\text { continuismo } \\
\text { Mejor condición de vida, } \\
\text { cambio }\end{array}$ \\
\hline
\end{tabular}

Desde el momento de su exposición en la publicidad, los íconos emblemáticos se fijan, se organizan en recurrencias esquemáticas tan habituales que permiten analizar una es- tructura definida, de combinaciones particulares en cada línea política.

El imaginario político de ARENA estuvo configurado por una 
narrativa de antítesis con dimensiones ideales, grandilocuentes y jerárquicamente planificadas; la diferenciación y la exclusión son los principios lógicos de significación capaces de acentuar un discurso cuya identificación con un grupo minoritario implique el alejamiento completo de otro grupo mayor entendido como amenaza social.

La enumeración iconográfica aludió a imágenes arquetípicas cuya presencia manifestó la distinción marcada entre lo legítimo y lo ilegítimo, lo aceptado y lo rechazado, el presente estable o el futuro en retroceso, una postura tan unidireccional y radical en la que se estableció, por un lado, la posición dominante del partido y sus símbolos patriarcales, ordenadores y rectores del sistema de vida salvadoreño, la estabilidad económica y el desarrollo ciudadano, y por otro, la construcción imaginaria de la patria equivalente a ARENA; Votar por El Salvador es votar por ARENA, un desplazamiento sustantivo de significaciones absolutas que definen la unidad dominante de la derecha.

La relación inmediata de partido-pueblo se definió como dependencia tutelar, subsidiaria, protectora, en la que el patriarca cobró dimensiones ideales, omnipotentes y jerárquicamente planificadas, beneficiando con su dirigencia al campesino, el joven, la madre salvadoreña, el obrero; todos ellos dibujados como buenos ciudadanos, libres, creyentes y ahora expuestos a la pér- dida de su patria. En la articulación narrativa de la publicidad, el partido se presentó como el único que beneficia o potencia el progreso y el desarrollo y el pueblo como el que recibe; ello puntualizó una lectura unidireccional de gestión en la que el desarrollo del pueblo salvadoreño se reduce a la posibilidad de 'acceso $a^{\prime}$ y no como 'progreso de'.

La imagen de la nación en la publicidad de ARENA adquiere los registros simbólicos ortodoxos de la iconografía medieval en la que el reino, el ejido o el feudo se organiza alrededor de la fe, el patriarca o el caudillo. Una nación en presente durativo, tan estática y sedentaria, como hegemónica y conformista. Los valores fueron expresados como dogmas incuestionables establecidos por la fe, la moral y la confianza absoluta hacia el partido. Por el contrario, el enemigo adoptó la imagen de la delincuencia, el crimen y las fuerzas subversivas desestabilizadoras con proporciones superlativas capaces de demandar la necesidad de la defensa. Dicho de otra forma, la construcción de un súper enemigo facilita la demanda de un súper héroe. Por ejemplo: el primer ícono del enemigo público fue Salvador Sánchez Cerén, presentado como "tres veces más asesino" que cualquier sicario, delincuente o líder de bandas delincuenciales; esa idealización negativa del oponente posteriormente adoptó la narrativa del 'lado oscuro de la fuerza', el archienemigo de los valores y de la nación en la imagen amenazante de Hugo Chávez. 
Esta escenificación alegórica del peligro, el caos, el Apocalipsis o la posibilidad del fin fue acompañado por recurrentes alusiones a la estabilidad de la sociedad salvadoreña donde las figuras humanas se convirtieron en préstamos mitológicos de la tradición cristiana fundamentalista, poses heroicas e imágenes nacionalistas de patriaciudadano con una línea discursiva monotemática y limitada cuyos objetivos políticos estaban orientados a condicionar la voluntad del ciudadano y corregir la posibilidad de simpatía por el oponente.

Por otra parte, las mismas constantes iconográficas se percibieron en la parte final de la publicidad del FMLN, pero consolidando un discurso comparativo, evaluador, y fiscalizador en el que se apeló a la conciencia del ciudadano salvadoreño como principal forma de defender los valores nacionalistas repetidos en la publicidad de ARENA. De hecho, puede afirmarse que en esta parte de la campaña del FMLN, los espots adecuan convenientemente los íconos de la publicidad de la derecha, retomando personificaciones, alegorías y símbolos estereotipados, pero con un énfasis distinto. La campaña se homogenizó visualmente, se posesionó de íconos rutinarios que la derecha había mantenido con exclusividad y abordó con ellos un amplio cuestionamiento.

El señalamiento, la deficiencia y el desengaño marcó la diferencia narrativa y discursiva de la campaña del FMLN, al mismo tiempo que se observaron imágenes alegóricas de esperanza, decisión, triunfalismo del pueblo salvadoreño en diversos colectivos, fue la exposición plástica de la inclusión, visualizado en la participación diversos colectivos, clases sociales y trabajadores en variados rubros profesionales. Los mensajes se dividían notablemente en dos momentos narrativos: la exposición de los problemas estructurales, las deficiencias administrativas y de gestión del gobierno, la especulación perjudicial o la falta de oportunidades y desarrollo digno en el pueblo salvadoreño (generalmente monologado por un obrero, un campesino, un joven, una mujer, madre trabajadora) y posteriormente la resolución categórica del cambio por un nuevo gobierno.

A diferencia de la campaña de la derecha, la publicidad del FMLN define el tiempo como una acción de recuerdo, enumeración y evaluación personal para un cambio específico. El futuro se construye a partir de la madurez en las decisiones, por ende un voto por el FMLN será un voto conciente, razonado y proactivo. El pueblo no es un pueblo doméstico sino una sociedad inclusiva, representada por el campesino, el joven, el obrero, la madre, el hermano lejano, quienes se visualizan como desengañados, afectados por las falsas promesas y el privilegio del gobierno hacia unos pocos. Una postura discursiva dialéctica en la que los antagonistas se confron- 
tan y se razona la mejor opción, la que propone la inclusión, el desarrollo como cambio continuo hacia una meta final: la integridad social y ciudadana en el trabajo digno, acceso a la educación, la salud y la estabilidad económica.

Como se puede observar, la campaña del 2009, en ambos partidos, propició la homogenización de los formatos de difusión, apeló a imágenes estereotipadas de la sociedad salvadoreña, a préstamos simbólicos de la mitología cristiana y a heráldicas de batalla con emblemas ideologizantes propios de cada línea política. La similitud de mensajes produjo, sin embargo, variantes narrativas y discursivas condicionado por la línea particular de cada partido en contienda. Cada una de estas constantes iconográficas indujo a un mensaje segregante por parte de ARENA y dialéctico incluyente por parte del FMLN.

\section{Consideraciones finales:}

- I estudio de la publicidad política en El Salvador es una forma de evaluar los imaginarios que construyen las representaciones sociales del Estado salvadoreño. El abordaje de las campañas, entendidas como textos que influyen en la interpretación del entorno socio político, evidencia la articulación ideológica de las imágenes con atribuciones y valores nacionalistas condicionados por los principales correctivos sociales moralizantes, presentes en los valores sociales, morales, religiosos y éticos.

La condición socializada del salvadoreño se presenta en estos mensajes como obediente a la construcción de la nación que se define en la fe, la libertad y la democracia, traducidos como valores patrios y publicitariamente vividos como resultado del desarrollo social. Sin embargo, sirven solamente como atributos ideologi- zados para consolidar una institución política y motivar la democracia del pueblo en el procedimiento del voto.

La orientación hacia el voto consciente no trascendió los niveles básicos de una competencia entre bandos opuestos, de hecho, el proselitismo se enfocó a observar al oponente como enemigo a someter y anular por parte de ARENA y su cruzada por la fe, la familia y la libertad o como antagonista a cuestionar y fiscalizar en la publicidad del FMLN y su teatralización del pueblo triunfalista. Ambas instituciones emplearon símbolos de rutina ya estereotipados en la publicidad salvadoreña, homogenizaron los formatos publicitarios y presentaron una estructura narrativa que definía su línea política, pero a su vez evadía el mensaje ortodoxo que había mantenido en campañas anteriores cada instituto en contienda. 

Madrid, edit. Cátedra.

Goffman, Irving. 1979, Relaciones en público, micro estudios de orden

público. Alianza Edit. España.

Gubern, Roman . 1987. La mirada opulenta. Edit. GG, España.

Thomas, Karin. 1988. Hasta hoy, estilo de las artes plásticas en el siglo XX. Edit Serbal, España. 